\title{
The Mediating Effect of Classroom Learning Environment on the Relationship Between Filipino Language Anxiety and Coping Strategies
}

\author{
Arnel II S. Bernal \\ Department of Teacher Education, UM Digos College, Philippines \\ arnel.bernal@umindanao.edu.ph \\ https://orcid.org/0000-0003-3263-0456
}

DOI: http://doi.org/ 10.36892/ijlls.v3i4.725

\begin{tabular}{|c|c|}
\hline & Abstract \\
\hline $14 / 10 / 2021$ & This study aims to identify the effect of the classroom-learning environment as \\
\hline $\begin{array}{l}\text { Accepted: } \\
\text { 15/11/2021 }\end{array}$ & $\begin{array}{l}\text { a mediator on the relationship between Filipino language anxiety and the } \\
\text { coping strategies of college students. This research was undergone by } \\
\text { quantitative research design using descriptive and correlation method via } \\
\text { mediation analysis. This study uses stratified random sampling; the data was }\end{array}$ \\
\hline $\begin{array}{l}\text { Keywords: } \\
\text { Filipino language } \\
\text { anxiety, classroom } \\
\text { learning } \\
\text { environment, coping } \\
\text { strategies, mediation, } \\
\text { regression, } \\
\text { Philippines }\end{array}$ & $\begin{array}{l}\text { gathered using survey questionnaires involving } 300 \text { respondents from first-year } \\
\text { colleges to fourth-year college) students. In response to the hypothesis of this } \\
\text { study, correlation analysis was used together with the Pearson r and Mediation } \\
\text { Analysis using Sobel z Test. The result has shown that Filipino language anxiety } \\
\text { and coping strategies have a strong and positive relationship. A strong and } \\
\text { positive relationship was also found between Filipino language anxiety and } \\
\text { classroom learning environment and the relationship between classroom } \\
\text { learning environment and coping strategies. Furthermore, using the Sobel z } \\
\text { test, the research found that the effect of the classroom-learning environment } \\
\text { partially mediated the relationship between Filipino language anxiety and } \\
\text { coping strategies. }\end{array}$ \\
\hline
\end{tabular}

\section{INTRODUCTION}

The study in Iranian University findings showed that the students usually considered a problem as uncontrollable. Hence, students used it as an avoidance strategy. Such as cognitive avoidance seeking alternative rewards, making positive reappraisal compared to their peers with an uncontrollable situation (Aguilar-Vafaie \& Abiari, 2007) mentioned in Gustems-Canicer, Calderón - Garrido (2019). Deasy et al., 2016 cited in Gustems - Canicer et al., 2019) stated that cognitive avoidance harms academic achievement. On the other hand, other studies found that students want to avoid their emotional health or mental health. They preferred to use the maladaptive stress response. Mentioned in the survey of Gustems - Carnicer et al. (2019), the reactions of this stress is use drugs (alcohol, tobacco, and Cannabis) as an alternative reward (Butler, Dodge, \& Faurote \& Sun et al., 2010) and harmful diet (Tavolacci et al, 2013).

Coping strategies stabilizing factors may help to particular individual in Psychological Adaptation from a tense situation. Students usually use coping to alleviate anxiety, time management, support from society, positive evaluation, and engaging good intention (Walton, 2002 cited in Bamuhair, et al., and 2015). Coping strategies effectively help students deal with difficult situations, such as fear and fear of failure inherent to be self-harm (Moir, 2014; Sayeh \& Razkane, 2021). Two coping strategies can help alleviate stress and anxiety (Folkman \& Lazarus, 1984 mentioned by Baqutayan, 2015). Problem-focused coping helps change the stressful situation 
by adjusting the problem and making emotion-focused alertness to fix stressful emotions. Concerning language anxiety and coping strategies, Kondo and Ying-Ling, 2004 mentioned in Marwan (2016) believe that language anxiety can be alleviated from actual learning by using coping strategies. To language anxiety and the classroom learning environment (Fareh, 2010 cited in Alrabia, 2015), noted that the teacher is part of reducing anxiety strategies such as letting students train to talk to themselves before speaking in the classroom and the avoidance of correcting the student's mistake in front of the students will cause a decrease in communication comprehension and fear of negative evaluation. He (2017) suggested on the relationship of the classroom learning environment and coping strategies that the effective coping strategy was the personal characteristic of the teacher. Being a humorist was one of the effective coping strategies for students with Foreign Language Speaking Anxiety or FLSA. The study of the classroom learning environment as a mediator on the relationship between Filipino language anxiety and coping strategies has not yet been evaluated. Especially on the factors from the classroom learning that cause anxiety in the Filipino language to the students. No study has yet been conducted to determine the level of Filipino language anxiety of the students and identify the coping strategies to anticipate language anxiety. This research will be conducted to determine students' level of anxiety in the Filipino language as a second language used, whether academic or communication. This research will determine whether the classroom learning environment significantly affects the relationship between Filipino language anxiety and coping strategies.

\subsection{Purpose of the Study}

The purpose of this paper is to examine the effect of the classroom learning environment on the relationship between Filipino language anxiety and coping strategies among college students of UM Digos College. To determine the level of students' anxiety on the Filipino language and what coping strategies they use to alleviate the anxiety.

\subsection{Research Questions}

1. What is the level of anxiety in the Filipino language among college students?

2. What is the effect of coping strategies on the anxiety of the students?

3. What is the effect of classroom learning environment on the relationship between Filipino language anxiety and coping strategies?

4. Is there a significant relationship between Filipino language anxiety and coping strategies, Filipino language anxiety and classroom learning environment, and the classroom-learning environment and coping strategies.

\section{LITERATURE REVIEW}

In this section, different literature and studies from various authors that impact this study will be presented. Readers in this study will gain knowledge and characteristics of the following: the effects of anxiety on the Filipino language, coping strategies that can be used when they experience a stressful and anxious situation, and the quality of the classroomlearning environment will be identified.

\subsection{Filipino Language Anxiety}

Language anxiety reflects anxiety and adverse emotional reactions (Gregersen \& MacIntyre, 2014). Sharpening a second language can be a daunting experience (Quintos, 2021). Four factors may have been the leading cause of language anxiety. First, communication anxiety is the fear of communicating with other people (James McCroskey, 1997) and the cause of anxiety of students (Debreli \& Demirkan, 2015). Second, test anxiety involves various influences that cause students 'performance (Djebbari \& Benmostefa, 2019), such as if they do not have time to study, do not answer questions well, and do not see test questions (Himat \& Nazari, 2019). Third, fear of negative evaluation is the reason for the difference in how each 


\section{Anxiety and Coping Strategies}

individual's information is processed (Button, Kounali, Stapinski, et al., 2015). Finally, the anxiety in the Filipino language was detected by various factors in the study conducted by Ancheta and Perez (2017), such as the lack of a teacher to give them enough time to teach them Filipino when their students are absent. Friends who can translate lack books, modules, etc., and are ashamed to speak Filipino.

\subsection{Coping Strategies}

Coping strategies are the process that manages "stress" or distress (Gustems-Carnicer, et al., 2019) and helps combat anxiety (Wei, 2012). The five (5) coping strategies to be used to relieve anxiety is the preparation to overcome the feeling of anxiety or fear (Kondo \& Ling, 2004) mentioned by Marwan (2016). Second, relaxation relieves fear by breathing deeply (Grasha, 1987) mentioned in the study of Mahmud and Suryana (2015). Third, positive thinking to control negative emotions (Mahmud \& Suryana, 2015) and the most effective language learning method to anticipate language anxiety (Yasuda (2018). Fourth, finding the same to predict anxiety by comparing themselves to others (Mahmud \& Suryana, 2015) and the strategy-fit to be used as documentation about the importance of being with Ryan and Shim (2012) mentioned in the study by Cooc and Kim (2017). Finally, resignation is giving up, stopping paying attention, accepting the situation, making any effort, even sleeping in class (Mahmud \& Suryana, 2015).

\subsection{Classroom Learning Environment}

The classroom learning environment is the place with proper arrangement and use of space (Kausar, Kiyani \& Suleman, 2017 cited by Adebola, 2020) \& Cantero, Muñoz, Mira, \& Lopez-Chao, 2016). There is adequate ventilation in the classroom (Haverinen-Shaughnessy and Shaughnessy, 2015) to maintain a suitable temperature (Cheryan, Ziegler, Plaut, and Meltzoff, 2014), and students will feel comfortable (Ryan, 2012 mentioned by Ramli, Campus, and Chepa, 2018). When the classroom is surrounded by a green landscape (Li \& Sullivan, 2016) and many trees will significantly give students good performance on the exam (Kweon, Ellis, Lee \& Jacobs, 2017). In addition, Zhang and Zhong (2012) cited the teacher as one of the factors that added anxiety to the language classroom and their classroom skills, so, Fareh (2010), cited by Alrabai (2016) suggested the teacher should be part of anxiety reduction strategies. Additionally, Bhusal's (2020) study implies that educators need to help their students develop speech knowledge awareness procedures and allow the ruling class to use a wider range of appropriate approaches to intensify their conversational competence in English.

\section{THEORETICAL FRAMEWORK}

This study is supported by "The transactional theory of stress and coping" developed by Lazarus and Folkman (Lazarus; Lazarus and Folkman, 1984) mentioned by Biggs, Brough, and Drummond (2017) as a particular instrument in sharpening "Stress" and alertness. It focuses on directing to reduce stressors and alleviate emotional distress arising from negative individual or environmental transactions. Folkman revised this (cited by Biggs, et al., 2017), describing two (2) "key areas" to be developed: (first) the use of positive emotions in the "stress" process and the preparedness process, and (second) the role of alertness processes in facilitating positive emotions during intense, stressful events.

This theory is supported in the relationship between language anxiety and coping strategies. Kondo and Ying-Ling (2004) believe in alleviating language anxiety if they use alertness strategies from actual learning. Pappamihiel (2002), cited by Marwan (2016), revealed that avoidance or resignation is one of the prevention strategies often used by students as a strategy to alleviate their language anxiety. In addition, a proactive approach means as a 
process to manage "stress" that each will make cognitive and behavioral efforts to address two sources of stress external or internal (Moos, 1993 cited by Gustems-Carnicer, et al., 2019).

\section{METHODOLOGY}

This study used quantitative non-experimental design research using the correlation technique. This research method is suitable for the study because of the purpose of determining the significant relationship of an independent variable and dependent variable, including the influence of independent variable on a dependent variable, independent variable on a mediator, and mediator on a dependent variable. This study was conducted in Digos City involving $\mathrm{N}=300$ college students. Stratified random sampling was used in selecting students to consider for the Final sample. Three adapted questionnaires were used to gather information on the condition held in the study. The research tools had minimal revisions and were submitted to a panel of experts for validation. The first part of the questionnaire is an adapted questionnaire developed by Horwitz, Horwitz, and Cope (1986) dealing with Filipino Language Anxiety. The second part of the questionnaires is "adapted questionnaires" designed by Kondo and Ying-Ling (2004) that focus on the study of Coping Strategies. The third set of questionnaires was an adapted questionnaire developed by McGhee, Lowell, and Lemire (2007) based on the Classroom Learning Environment. This study underwent "pilot testing" before the study was conducted. Based on the results, the items in the questionnaires were reliable, with a Cronbach's alpha result greater than 0.7.

Upon approval, the researcher set aside time to conduct the study with the dean in administering the survey to the students. Due to the COVID-19 or pandemic, data collection was carried out using a google form to avoid being infected with such a disease or virus, which has become a problem around the world. The researcher posted the instructions on google drive that respondents were expected to do. Respondents answered the questionnaire within 20 minutes to 30 minutes. After the respondents answered the questions, the researcher transferred the data in google drive to excel or a spreadsheet to be submitted to the statistician to calculate and get the result. After being calculated, the researcher gave an interpretation of the result to the collected data. This study was calculated the data, the mean was used to determine the level of anxiety Filipino language anxiety and coping strategies, Filipino language anxiety, and classroom learning environment, and classroom learning environment and coping strategies of the students. Pearson $r$ was used to identify significant relationships between Filipino language anxiety and coping strategies, Filipino language anxiety and classroom learning environment, and classroom learning environment and alertness strategies of students. Study. Regression was used to determine which domain of anxiety in the Filipino language significantly influenced students' coping strategies and the classroom environment. Sobel z-test in turn to assess the significant effect of the mediator. It is used only when the three steps in the med-graph (paths a, b, and c) are significant. This calculation is done using the "Statistical Package for the Social Sciences" (SPSS).

\section{RESULTS AND DISCUSSION}

In this part are the data and the analysis of the findings based on the respondents 'responses to anxiety in the Filipino language, preparedness strategies, and classroom learning environment. The tables are arranged under the following headings: level of anxiety in the Filipino language, quality of the classroom learning environment, the extent of the preparedness strategy, a significant correlation of anxiety in the Filipino language, alertness strategy and the classroom environment- learning, and the mediating effect of the classroom 
learning environment on the relationship of anxiety in the Filipino language and coping strategies.

\subsection{Level of Filipino Language Anxiety}

Table 1 shows the data on the level of Filipino language anxiety of the respondents. The table below presents the total mean score for which the level of anxiety in the Filipino language obtained 3.56 or higher. It indicated here that the condition associated with anxiety in the Filipino language was often noticed. The mentioned total "mean score" is a result of the collected data provided by the respondents on each item of anxiety in the Filipino language. The high level obtained these items: 3.68 test anxiety; 3.60 Communication anxiety apprehension; Filipino anxiety scored 3.58. Furthermore, finally, the negative evaluation, which scored 3.37.

Table 1. Level of Filipino Language Anxiety

\begin{tabular}{|c|c|c|c|}
\hline Indicators & SD & Mean & $\begin{array}{l}\text { Descriptive } \\
\text { Level }\end{array}$ \\
\hline Communication anxiety apprehension & 0.69066 & 3.60 & High \\
\hline Test anxiety & 0.69836 & 3.68 & High \\
\hline Negative evaluation & 0.67925 & 3.37 & High \\
\hline Filipino Anxiety & 0.63513 & 3.58 & High \\
\hline Overall & 0.63194 & 3.56 & High \\
\hline
\end{tabular}

\subsection{Level of Coping Strategies}

Table 2 shows the data on the coping strategies of UM Digos College students who obtained a total "mean" of 3.59 or higher. It was indicated that the coping strategies were frequently used by the respondents, such as preparation (3.93), positive thinking (3.93), peer seeking (3.62), and relaxation (3.49), except for the resignation item which scored 2.97 that "mean score" or average level. It is indicated here also that coping strategies are sometimes used.

Table 2. Level of Coping Strategies

\begin{tabular}{|c|c|c|c|c|}
\hline & Indicators & $\mathrm{SD}$ & Mean & $\begin{array}{l}\text { Descriptive } \\
\text { Level }\end{array}$ \\
\hline Preparation & & 0.71807 & 3.93 & High \\
\hline Relaxation & & 0.76048 & 3.49 & High \\
\hline Positive thinking & & 0.70496 & 3.93 & High \\
\hline Peer seeking & & 0.68410 & 3.62 & High \\
\hline \multirow[t]{3}{*}{ Resignation } & & 0.73698 & 2.97 & Moderate \\
\hline & Overall. & 0.54400 & & \\
\hline & & & 3.59 & High \\
\hline
\end{tabular}

\subsection{Level of Classroom Learning Environment}

Table 3 shows the data for the items of the classroom learning environment with a total mean score of 3.75 or higher. It indicated here that the classroom learning environment is often affected - the high score proceeds from the high score given by the respondents from the items. The cited total mean score is a result of the collected data provided by the respondents on each item of the classroom learning environment. Respondents 'responses will be presented from highest to lowest, according to their mean value. These are the following items: the critical part 
of my college education is to learn about different cultures or perspectives (4.40), and this class will provide an environment that is free and open to the expression of ideas, opinions, and beliefs (4.33) which has a higher level. It is implied here that the classroom learning environment is always affected.

The items that got high levels: the teacher felt that I was accepted in this class (4.17), the teacher encouraged the equal participation of all students in this class (4.13), I was satisfied to discuss courses that challenge my beliefs and values (4.13), I enjoy talking to people with values different from mine (4.10). The high level is the following: The classroom learning environment is conducive and accessible for students with disabilities, 3.90 marks are assigned equally and unconditionally in this class (3.70); I am usually ignored when I try to participate (3.70). It is indicated here that the classroom learning environment is often affected. Meanwhile, the following item got a moderate level: sometimes I felt like I was alone in this class because I was different; most of the students (2.83) and (2.67) felt like I was alone. It is implied here that the classroom learning environment is sometimes affected.

Table 3. Level of Classroom Learning Environment

\begin{tabular}{|c|c|c|c|}
\hline Items & SD & Mean & $\begin{array}{l}\text { Descriptive } \\
\text { Level }\end{array}$ \\
\hline $\begin{array}{l}\text { This class will provide an environment that is free and open } \\
\text { to expressing ideas, opinions, and beliefs. }\end{array}$ & 0.88409 & 4.33 & Higher \\
\hline $\begin{array}{l}\text { The critical part of my college education is to learn about } \\
\text { different cultures or perspectives. }\end{array}$ & 0.72397 & 4.40 & Higher \\
\hline $\begin{array}{l}\text { Sometimes I felt like I was alone in this class because I was } \\
\text { different from most students. }\end{array}$ & 1.37 & 2.83 & Moderate \\
\hline Marks are assigned equally and unconditionally in this class. & 1.08755 & 3.70 & High \\
\hline $\begin{array}{l}\text { I was satisfied to discuss courses that challenged my beliefs } \\
\text { and values. }\end{array}$ & 0.81931 & 4.13 & High \\
\hline I am usually ignored in class when I try to participate. & 0.83666 & 3.70 & High \\
\hline $\begin{array}{l}\text { The classroom learning environment is conducive and } \\
\text { accessible for students with disabilities. }\end{array}$ & 0.84486 & 3.90 & High \\
\hline $\begin{array}{l}\text { The teacher encouraged the equal participation of all students } \\
\text { in this class. }\end{array}$ & 0.81931 & 4.13 & High \\
\hline The item felt like I was alone in the class. & 1.29544 & 2.67 & Moderate \\
\hline I enjoy talking to people with values different from mine & 0.88474 & 4.10 & High \\
\hline \multirow[t]{2}{*}{ The teacher felt that I was accepted in this class. } & .79148 & 4.17 & High \\
\hline & 0.66970 & 3.75 & High \\
\hline Overall & & & \\
\hline
\end{tabular}

5.4. Significant Relationship Between Filipino Language Anxiety and Coping Strategies

Table 4.1 below presents the results of the relationship between Filipino language anxiety and the coping strategies of college students. In the in-depth analysis, it can be seen that the overall result of the relationship between anxiety in the Filipino language and coping strategies was found to have an "r-value" of 0.631 with a probability value of $<0.001$, which is less than the significant 
level of 0.05. It shows that there is a significant relationship between Filipino language anxiety and coping strategies. Given a $<0.001$ p-values, it means rejecting the "null hypothesis," stating no significant relationship between Filipino language anxiety and coping strategies. As evidenced in the table, the r-value and p-value in the relationship of anxiety in the Filipino language and coping strategies are 0.631 and $<0.001$ probability value or significant. The data indicate that Filipino language anxiety is an essential indicator of coping strategies.

Table 4.1. Significant Relationship Between Filipino Language Anxiety and Coping Strategies

\begin{tabular}{|c|c|c|c|c|c|c|}
\hline \multicolumn{7}{|c|}{ Coping Strategies } \\
\hline $\begin{array}{l}\text { Language } \\
\text { Anxiety }\end{array}$ & Preparation & Relaxation & $\begin{array}{l}\text { Positive } \\
\text { thinking }\end{array}$ & $\begin{array}{l}\text { Peer } \\
\text { seeking }\end{array}$ & Resignation & $\begin{array}{l}\text { Coping } \\
\text { Strategies } \\
\text { (Overall) }\end{array}$ \\
\hline \multicolumn{7}{|l|}{ Communication } \\
\hline Anxiety & $.690^{* * *} .000$ & $.357^{* *}$ & $.600^{* *}$ & $.521^{* *}$ & $.149^{* *}$ & $.609^{* *}$ \\
\hline Apprehension & & .000 & .000 & .000 & .010 & .000 \\
\hline \multirow[t]{2}{*}{ Test Anxiety } & $.677^{* *} .000$ & $.284^{* *}$ & $.589^{* *}$ & $.481^{* *}$ & .095 & $.558^{* *}$ \\
\hline & & .000 & .000 & .000 & .100 & .000 \\
\hline Negative & $.601^{* * *} .000$ & $.303^{* *}$ & $.527^{* *}$ & $.495^{* *}$ & $.147^{*}$ & $.545^{* *}$ \\
\hline Evaluation & & .000 & .000 & .000 & .011 & .000 \\
\hline \multirow[t]{2}{*}{ Filipino Anxiety } & $.736^{* * *} .000$ & $.387^{* *}$ & $.655^{* *}$ & $.535^{* *}$ & $.169^{* *}$ & $.652^{* *}$ \\
\hline & & .000 & .000 & .000 & .003 & .000 \\
\hline Filipino & $.722^{* *} .000$ & $.355^{*}$ & $.633^{* *}$ & $.542^{* *}$ & $.149^{* *}$ & $.631^{* *}$ \\
\hline Language & & .000 & .000 & .000 & .010 & .000 \\
\hline $\begin{array}{l}\text { Anxiety } \\
\text { (Overall) }\end{array}$ & & & & & & \\
\hline
\end{tabular}

\subsection{Significant Relationship Between Filipino Language Anxiety and Classroom Learning Environment}

Table 4.2 below shows the results of the relationship between Filipino language anxiety and the classroom learning environment of college students. In the in-depth analysis, it can be seen that the overall impact on the relationship between Filipino language anxiety and classroom learning environment obtained $0.606 \mathrm{R}$-values with $<0.001 \mathrm{p}$-value, which is less than the significant level of 0.05 . shows that there is a significant relationship between Filipino language anxiety and the classroom learning environment. Given a p-value of $<0.001$, it means that the null hypothesis stating that there is no significant relationship between Filipino language anxiety and the classroom learning environment is rejected.

Table 4.2. Significant Relationship Between Filipino Language Anxiety and Classroom Learning Environment

Filipino Language Anxiety

Classroom Learning Environment

Classroom Learning
Environment
(Overall)




\begin{tabular}{ll}
\hline Communication Anxiety Apprehension & $.577^{* *}$ \\
& $(.000)$ \\
Test Anxiety & $.574^{* *}$ \\
& $(.000)$ \\
Negative Evaluation & $.491^{* *}$ \\
& $(.000)$ \\
Filipino Anxiety & $.627^{* *}$ \\
& $(.000)$ \\
Filipino Language Anxiety & $.606^{* *}$ \\
(Overall) & $(.000)$ \\
\hline
\end{tabular}

\subsection{Significant Relationship Between Classroom Learning Environment and Coping Strategies}

Table 4.3 below shows the results of the relationship between the classroom learning environment and coping strategies. In the in-depth analysis, the overall effect in the relationship of the classroom learning environment and coping strategy obtained $0.726 \mathrm{R}$-values with $<0.001$ probability value which is less than the significant level of 0.05 . This result indicated that there was a significant correlation between the classroom learning environment and coping strategies. At a p-value of $<0.0001$, this means that there is strong evidence that the null hypothesis is rejected, stating that there is no significant relationship between the classroom learning environment and the promptness strategy.

Table 4.3. Significant Relationship Between Classroom Learning Environment and Coping Strategies

\begin{tabular}{lllllll}
\hline $\begin{array}{l}\text { Classroom } \\
\begin{array}{l}\text { Learning } \\
\text { Environment }\end{array}\end{array}$ & Preparation & Relaxation & $\begin{array}{l}\text { Positive } \\
\text { thinking }\end{array}$ & Peer seekinє Resignatior $\begin{array}{l}\text { Coping } \\
\text { Strategies } \\
\text { (Overall) }\end{array}$ \\
\hline $\begin{array}{l}\text { Classroom } \\
\text { Learning }\end{array}$ & $.728^{* *}$ & $.455^{* *}$ & $.743^{* *}$ & $.660^{* *}$ & $.180^{* *}$ & \\
$\begin{array}{l}\text { Environment } \\
\text { (Overall) }\end{array}$ & $(.000)$ & $(.000)$ & $(.000)$ & $(.000)$ & $(.002)$ & .726 \\
\hline
\end{tabular}

5.7.The Mediating Effect of Classroom Learning Environment on the Relationship Between Filipino Language Anxiety and Coping Strategies

Using Path Analysis, the path of FLA (X) to CLE (M) was shown; CLE (M) to CS. (Y); and FLA (X) towards CS. (Y) is significant with "sign unchanged." Therefore, CLE partially mediates the relationship between FLA and CS. Figure 3 shows that each unit in Filipino Language Anxiety has a corresponding unit increase of 0.642 in the Classroom Learning Environment. Also, for each anxiety unit in the Filipino Language, there is a corresponding unit increase of 0.259 in the Coping Strategies. Moreover, there is a corresponding 0.442 unit increase in Coping Strategies for each unit increase in the Classroom Learning Environment.

In summary, for each unit increase in Filipino Language Anxiety, the following FLACLE-CS paths have 0.259 units increase in the Coping Strategies. The result found that Filipino Language Anxiety can enhance the Coping Strategies but needed to go through an enhanced 
Classroom Learning Environment. As a result, higher levels of the Classroom Learning Environment mediate Filipino language anxiety to enhance students' coping strategies.

\begin{tabular}{lllllll}
\hline & & Estimate & S.E. & C.R. & P & Label \\
\hline CLE <--- & FLA & .642 & .049 & 13.172 & $* * *$ & \\
C.S. <--- & FLA & .259 & .040 & 6.429 & $* * *$ & \\
C.S. <--- & CLE & .442 & .038 & 11.619 & $* * *$ & \\
\hline
\end{tabular}

\section{SUMMARY OF FINDINGS AND CONCLUSION}

This study shows high levels of Filipino language anxiety, high levels in the classroom learning environment, and similar to the coping strategies that got high levels from college students. The relationship between Filipino language anxiety and coping strategies indicates that there was a significant and positive relationship. The same result on the relationship between Filipino language anxiety and the classroom learning environment with a significant and strong and positive relationship and the relationship between classroom learning environment and coping strategies with a strong and positive relationship. In addition, the results show that the classroom learning environment significantly mediates the relationship between Filipino language anxiety and coping strategies. Thus, it means that the evidence is strong to reject the null hypothesis. The transactional theory of stress and coping developed by Lazarus and Folkman (Lazarus; Lazarus and Folkman, 1984) mentioned by Biggs, Brough, and Drummond (2017) is confirmed to be used by respondents to avoid Filipino language anxiety. Based on the result, coping strategies obtained a total mean or high level. The study indicated that the respondents frequently used preparation, positive thinking, peer seeking, relaxation. And except for the resignation item, which has obtained a moderate level which only used once.

\subsection{Recommendations for Further Research}

Based on previous findings and conclusions, the following recommendations are offered. Given the partially mediated effect of the classroom learning environment on the relationship of Filipino language anxiety and coping strategies, the UM Digos College administration can use the results of this study to provide quality education to their students. In particular, teachers of the Filipino language as the key to the operation of the classroom learning environment need to maintain or strengthen positive methods and practices, especially in highly satisfactory aspects. Further, develop parts that are less suggested and demonstrated, such as investigation and instructional support. The study indicated that the Human Resource Management of the institution provides professional development courses to Filipino language teachers to train them. Moreover, make sure they are aware of the complex issues related to the students' anxiety and status of the students. Study the classroom learning environment and prepare them with reasonable strategies to combat students 'language anxiety.

The study results suggested that the dean or the program leaders may continue to observe teachers' performance in teaching, especially those who teach the Filipino subject. It is imperative to assess the behavior of teachers while teaching in a language where a teacher's anxiety or frustration is likely to have an impact on the student. Procedures and practices within the classroom also need to be investigated to identify the "highly-rated" source of anxiety. In addition, give time and attention to find out the factors that led to this study. Finally, as the result of this study, the 
classroom learning environment had a significant and positive relationship between Filipino language anxiety and coping strategies. That affected various aspects of the research and learning of students, especially in language use, experience in the classroom learning environment, and the use of proactive strategies to alleviate language anxiety. Therefore, more research is expected from different students to solve current and future issues or problems.

\subsection{Implications for Theory, Research, and Practice}

The transactional theory of stress and coping developed by Lazarus and Folkman (Lazarus; Lazarus, \& Folkman, 1984) mentioned by Biggs, Brough, and Drummond (2017) is confirmed to be used by respondents to avoid anxiety in the Filipino language. Based on the result that obtained the overall mean or high level of the coping strategy. It is indicated here that it is frequently used by the respondents, such as preparation, positive thinking, finding the same, relaxation, and the resignation item, which has obtained a moderate level where this strategy is only used once. This study was conducted based on college students; therefore, it is also invited to conduct a study from elementary and secondary students when knowing their level of anxiety, impact brought by the classroom environment. Student learning and the level of use of promptness strategies to alleviate or alleviate language distraction. For future researchers, it is possible to continue conducting this research, especially among college students, to find out if there is any difference in the result after this study. This study can also research other areas or institutions related to language teaching based on their curriculum by using various methods and instruments to provide new results. Qualitative analysis of the results of this study also needs a recommendation before the results can be verified.

\section{REFERENCES}

Adebola, O. O. (2020). The use of supplemental instruction in university classrooms as a strategy to enhance the academic performance of first-year students. Universal Journal of Educational Research, 8(11B), 6289-6296.

Aguilar-Vafaie, M. E., \& Abiari, M. (2007). Coping Response Inventory: Assessing coping among Iranian college students and introductory development of an adapted Iranian Coping Response Inventory (CRI). Mental Health, Religion and Culture, 10(5), 489513.

Alrabai, F. (2015). The influence of teachers' anxiety-reducing strategies on learners' foreign language anxiety. Innovation in Language Learning and Teaching, 9(2), 163-190.

Alrabai, F. (2016). Factors underlying low achievement of Saudi EFL learners. International Journal of English Linguistics, 6(3), 21-37.

Ancheta, J. R., \& Perez, C. A. (2017). Language learning difficulties of selected foreign students in National University, Philippines. International Journal of Research, 6(4), 65-76.

Bamuhair, S. S., Al Farhan, A. I., Althubaiti, A., Agha, S., ur Rahman, S., \& Ibrahim, N. O. (2015). Sources of stress and coping strategies among undergraduate medical students enrolled in a problem-based learning curriculum. depression, 20, 33.

Baqutayan, S. M. S. (2015). Stress and coping mechanisms: A historical overview. Mediterranean Journal of Social Sciences, 6(2 S1), 479-479. 

COMPETENCE. International Journal of Language and Literary Studies, 2(3), 271279.

Biggs, A., Brough, P., \& Drummond, S. (2017). Lazarus and Folkman's psychological stress and coping theory. The handbook of stress and health: A guide to research and practice, 351-364.

Butler, A. B., Dodge, K. D., \& Faurote, E. J. (2010). College student employment and drinking: a daily study of work stressors, alcohol expectancies, and alcohol consumption. Journal of occupational health psychology, 15(3), 291.

Button, K. S., Kounali, D., Stapinski, L., Rapee, R. M., Lewis, G., \& Munafò, M. R. (2015). Fear of negative evaluation biases social evaluation inference: Evidence from a probabilistic learning task. PloS one, 10(4), e0119456.

Cantero, J. M. M., Mira, R. G., \& López-Chao3, V. (2016). Influence of physical learning environment in student's behavior and social relations. The Anthropologist, 25(3), 249-253.

Cheryan, S., Ziegler, S. A., Plaut, V. C., \& Meltzoff, A. N. (2014). Designing classrooms to maximize student achievement. Policy Insights from the Behavioral and Brain Sciences, 1(1), 4-12.

Cooc, N., \& Kim, J. S. (2017). Peer influence on children's reading skills: A social network analysis of elementary school classrooms. Journal of Educational Psychology, 109(5), 727.

Deasy, C., Coughlan, B., Pironom, J., Jourdan, D., \& Mannix-McNamara, P. (2016). Psychological distress and help seeking amongst higher education students: findings from a mixed method study of undergraduate nursing/midwifery and teacher education students in Ireland. Irish Educational Studies, 35(2), 175-194.

Debreli, E., \& Demirkan, S. (2015). Sources and levels of foreign language speaking anxiety of English as a foreign language university students with regard to language proficiency and gender. International Journal of English Language Education, 4(1), 49-62.

DJEBBARI, Ms Houda, and Nawel BENMOSTEFA.(2019). "Test Anxiety In Foreign Language Assessment: A Query To Pender 4.6

Fareh, S. (2010). Challenges of teaching English in the Arab world: Why can't EFL programs deliver as expected?. Procedia-Social and Behavioral Sciences, 2(2), 3600-3604.

Grasha, A. F. (1987). Short-Term Coping Techniques for Managing Stress. New directions for Teaching and Learning.

Gregersen, T., MacIntyre, P. D., \& Meza, M. D. (2014). The motion of emotion: Idiodynamic case studies of learners' foreign language anxiety. The Modern Language Journal, 98(2), 574-588.

Gustems-Carnicer, Jose, Caterina Calderón, \& Diego Calderón-Garrido.(2019). "Stress, coping strategies and academic achievement in teacher education students. "European Journal of Teacher Education 42.3:375-390. 
Haverinen-Shaughnessy, U., \& Shaughnessy, R. J. (2015). Effects of classroom ventilation rate and temperature on students' test scores. PloS one, 10(8), e0136165.

He, D. (2017). How to Cope with Foreign Language Speaking Anxiety Effectively? The Case of University Students in China.Electronic Journal of Foreign Language Teaching, 14(2).

Himat, A. N., \& Nazari, H. R. (2019). INVESTIGATING THE LEVEL OF TEST ANXIETY IN EFL STUDENTS'AT KANDAHAR UNIVERSITY, AFGHANISTAN. European Journal of English Language Teaching.

Horwitz, E. K., Horwitz, M. B., \& Cope, J. (1986). Foreign language classroom anxiety. The Modern language journal, 70(2), 125-132.

Kausar, A., Kiyani, A. I., \& Suleman, Q. (2017). Effect of classroom environment on the academic achievement of secondary school students in the subject of Pakistan studies at secondary level in Rawalpindi District, Pakistan. Journal of Education and Practice, 8(24), 56-63.

Kondo, D. S., \& Ying-Ling, Y. (2004). Strategies for coping with language anxiety: The case of students of English in Japan. ELT Journal, 58(3), 258-265.

Kweon, B. S., Ellis, C. D., Lee, J., \& Jacobs, K. (2017). The link between school environments and student academic performance. Urban Forestry \& Urban Greening, 23, 35-43.

Lazarus, R. S., \& Folkman, S. (1984). Stress, appraisal, and coping. Springer publishing company.

Li, D., \& Sullivan, W. C. (2016). Impact of views to school landscapes on recovery from stress and mental fatigue. Landscape and urban planning, 148, 149-158.

Mahmud, S., \& Suryana, A. (2015). Coping with Language Anxiety of Second Language Users: A Psychological Approach. The Journal of English Literacy Education: The Teaching and Learning of English as a Foreign Language, 2(1), 47-54.

Marwan, A. (2016). Investigating students' foreign language anxiety. Malaysian Journal of ELT research, 3(1), 19.

McCroskey, J. C., \& Kretzschmar, M. M. (1977). Communication apprehension and marital relationships of college graduates: An exploratory investigation. Eastern Communication Association.

McGhee, D. E., Lowell, N., \& Lemire, S. (2007). The classroom learning environment (CLE) questionnaire: Preliminary development. University of Washington Office of Educational Assessment.

Moir, A. (2014). Coping strategies for students. Education in the North, 21, 38-63.

Pappamihiel, N. E. (2002). English as a second language students and English language anxiety: Issues in the mainstream classroom. Research in the Teaching of English, 327-355.

Quintos, S. B. (2021). Examining the relationship between the foreign language anxiety and students'learning motivation to Filipino foreign language learners. Information Technology in Industry, 9(1), 645-658. 
Ramli, A., Zain, R. M., Campus, C., Chepa, P., \& Bharu, K. (2018). The impact of facilities on students' academic achievement. Sci. Int.(Lahore), 30(2), 299-311.

Ryan, A. M., \& Shim, S. S. (2012). Changes in help-seeking from peers during early adolescence: Associations with changes in achievement and perceptions of teachers. Journal of educational psychology, 104(4), 1122.

Sayeh, A. Y., \& Razkane, H. (2021). Moroccan High School EFL Teachers' Attitudes and Anxiety on Using Microsoft Teams Platform. TESOL and Technology Studies, 2(2), 29-40. https://doi.org/10.48185/tts.v2i2.267

Schaefer, J. A., \& Moos, R. H. (1998). The context for posttraumatic growth: Life crises, individual and social resources, and coping. Posttraumatic growth: Positive changes in the aftermath of crisis, 99, 126.

Tavolacci, M. P., Ladner, J., Grigioni, S., Richard, L., Villet, H., \& Dechelotte, P. (2013). Prevalence and association of perceived stress, substance use and behavioral addictions: a cross-sectional study among university students in France, 20092011. BMC public health, 13(1), 1-8.

Walton, R. L. (2002). A comparison of perceived stress levels and coping styles of junior and senior students in nursing and social work programs. Marshall University.

Wei, J., \& Yodkamlue, B. (2012). The Chinese Bouyei college students' classroom anxiety in foreign language learning: A survey study. International Journal of English Linguistics, 2(2), 75.

Yasuda, T., \& Nabei, L. (2018). Effects of coping strategies on language anxiety of Japanese EFL learners: Investigating willingness to communicate. Journal of Language Teaching \& Research, 9(5).

Zhang, R., \& Zhong, J. (2012). The hindrance of doubt: Causes of language anxiety. International journal of English linguistics, 2(3), 27.

\section{AUTHOR'S BIO}

Arnel II S. Bernal is a Licensed Professional Teacher and Associate Professor 1 in the Department of Teacher Education, UM Digos College, Philippines. He is teaching the Filipino language as his specialization, General Education subjects, and Professional Education subjects. 